\title{
A central role for Galectin 3 during renal epithelial cell morphogenesis after nephrectomy
}

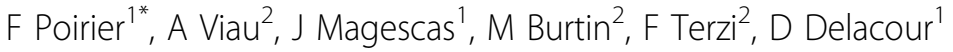 \\ From First International Cilia in Development and Disease Scientific Conference (2012) \\ London, UK. 16-18 May 2012
}

Galectin-3, a member of the multigene family of betagalactoside binding lectins, is mainly expressed in epithelial cells. The distribution of galectin-3 depends on cell type and cell differentiation. We previously showed that galectin-3 is transiently associated with the centrosome, and more specifically with the basal body at the basis of the primary cilium of MDCK cells. In the present study, we use galectin-3 null (Gal3-/-) mutant mice to investigate the functional consequences of our observations in the context of kidney regeneration after subtotal nephrectomy. Three months after surgery, renal functions were more severely affected in Gal3-/- mutant than in wt animals. Upon sacrifice, we found that Gal3-/- mutant kidneys were bigger and heavier, and this hypertrophy was associated with large tubular dilatations. Interestingly, in wt mice, galectin 3 intracellular distribution was altered in response to injury, displaying a distinct centrosomal localization in epithelial cells lining the collecting ducts close to the wound, whereas in cells away from the wound galectin-3 remained uniformly cytosolic. The impact of nephron reduction on primary cilium growth was examined by $3 \mathrm{D}$ reconstruction of wt and Gal3-/- renal tubules stained for acetylated alpha-tubulin. This analysis revealed that mutant primary cilia are irregular, bent, twisted and longer than wt primary cilia, indicating that Galectin-3 is essential for primary cilium growth. This suggests that the failure in kidney regeneration observed in Gal3-/- mutant mice may be due to defects in primary cilium biogenesis.

\section{Author details}

${ }^{1}$ Institut Jacques Monod CNRS Paris Diderot, France. ${ }^{2}$ INSERM U845, France.

Published: 16 November 2012

\footnotetext{
* Correspondence: poirier@ijm.univ-paris-diderot.fr

'Institut Jacques Monod CNRS Paris Diderot, France

Full list of author information is available at the end of the article
}

doi:10.1186/2046-2530-1-S1-P76

Cite this article as: Poirier et al:: A central role for Galectin 3 during renal epithelial cell morphogenesis after nephrectomy. Cilia 20121 (Suppl 1):P76.
Submit your next manuscript to BioMed Central and take full advantage of:

- Convenient online submission

- Thorough peer review

- No space constraints or color figure charges

- Immediate publication on acceptance

- Inclusion in PubMed, CAS, Scopus and Google Scholar

- Research which is freely available for redistribution

Submit your manuscript at www.biomedcentral.com/submit

\section{() Biomed Central}

